\title{
平均年最大流量と流域スケール \\ Mean annual flood and scale of catchment
}

\author{
葛葉泰久 1 -友杉邦雄 $2 \cdot$ Murugesu Sivapalan ${ }^{3}$ ・岸井徳雄 1 - 早野美智子 4 \\ Yasuhisa KUZUHA, Kunio TOMOSUGI, Murugesu SIVAPALAN, Tokuo KISHII \\ and Michiko HAYANO \\ 1正会員 博士 (工学) 防災科学技術研究所 ( T305-0006 つくば市天王台3-1) \\ 2 正会員 博士 (工学) 京都大学防災研究所(テ611-0011 宇治市五ヶ庄) \\ 3 非会員 Ph.D. University of Western Australia, Nedlands, Australia \\ 4正会員 博士 (学術) 防災科学技術研究所 ( 305-0006 つくば市天王台3-1)
}

\begin{abstract}
Recently, a lot of researchers have been interested in 'scale issues' in the research area of hydrology. 'Scale issues' include various questions to be solved, including lots of issues regarding runoff process. For example, the relationships between some hydrological processes which control runoff process and catchment scale have been studied. Recently, some researchers have tried to clarify the runoff system using mean annual flood (MAF) per unit area and coefficient of variation (CV) of annual flood.

In this study, analysis of runoff process by $\mathrm{CV}$ and MAF was carried out. First, CV/MAF versus catchment area were plotted for 285 catchments in Japan. Secondly, Eagleson's method was used in order to calculate MAF and $\mathrm{CV}$. The aim of this study is to develop model for numerical analysis of runoff, which will be combined to analysis by the data of 285 catchments. The model used in this study could estimate MAF qualitatively, but further consideration is necessary in regard to $\mathrm{CV}$.
\end{abstract}

Key Words: Coefficient of variation, Mean annual flood, Scale issues, Runoff, Catchment scale, Comparative hydrology

\section{1. 序論}

スケール問題的な視点で流出現象の解析を行う手法 の一つとして,「年最大流量の平均值」（Mean annual flood; 以下, MAFと称す)や「単位面積あたりのMAF」 (Specific MAF; 以下, SMAFと称す) と流域面積の関係, あるいは「年最大流量の変動係数」（以下, CVと称す） と流域面積をもとにする方法がある ${ }^{1,2)}$. 著者らはA/P FRIEND $^{3)}$ における比較水文学的研究の一環として, SMAFやCVを使った流出過程の解析を行い, 日本, Australia, アジア各国における流出過程の比較をするこ とによって, 流出過程の基礎的理解に資する知見を得 るとともに, 国・地域間での流出機構の共通点・相違点 を明らかにしようとしている. 現段階では日本における 流出データを用いて実際の流域でのSMAF等を求める 4)とともに,「数值計算的にSMAF等を求めるためのモデ ル」の構築を目的とした研究を行っている. 著者らはこ のようなモデルの必要性を，以下のように考える. すな わち，1）実流域でのSMAF等の傾向から流域の降雨一 流出過程に関わる現象解明を試みる際, 現象に関わる
種々のパラメータを変化させる, いわゆる「モデルによる 感度分析的な数值実験」の結果は有益な知見となる. 2) 「数值モデルで実流域でのSMAF, CV等の挙動を再現 できるか否か」といら検討, それに伴うモデルの改良を 通して,「降雨一流出過程」をより梁く理解できる, である. すでにBlöschl and Sivapalan"1) が CV, SMAF と流域 面積の関係に与える線形・非線形の様々な要因, 換言 すれば種々の水文過程におけるパラメータの影響を調 べている. そこでは降雨の継続時間, 強度, また流域の 非線形的な応答等による影響等が独自のモデルを用い て調べられているが, 著者らは, Eagleson ${ }^{5)}$ 手法を用 いることが研究目的から考えて適当であると考えた. そ の理由は, 現象が (経験式が少なく)解析的に取り扱わ れているため,ここまでで述べたような検討を「より現象 の本質を見ながら」進められると考えたからである.

本稿では, 上記の手法によりSMAF, CVを求め, 数 值モデルの妥当性と問題点, 今後の課題について検討 した結果を報告する.

\section{SMAF, CV と流域面積}



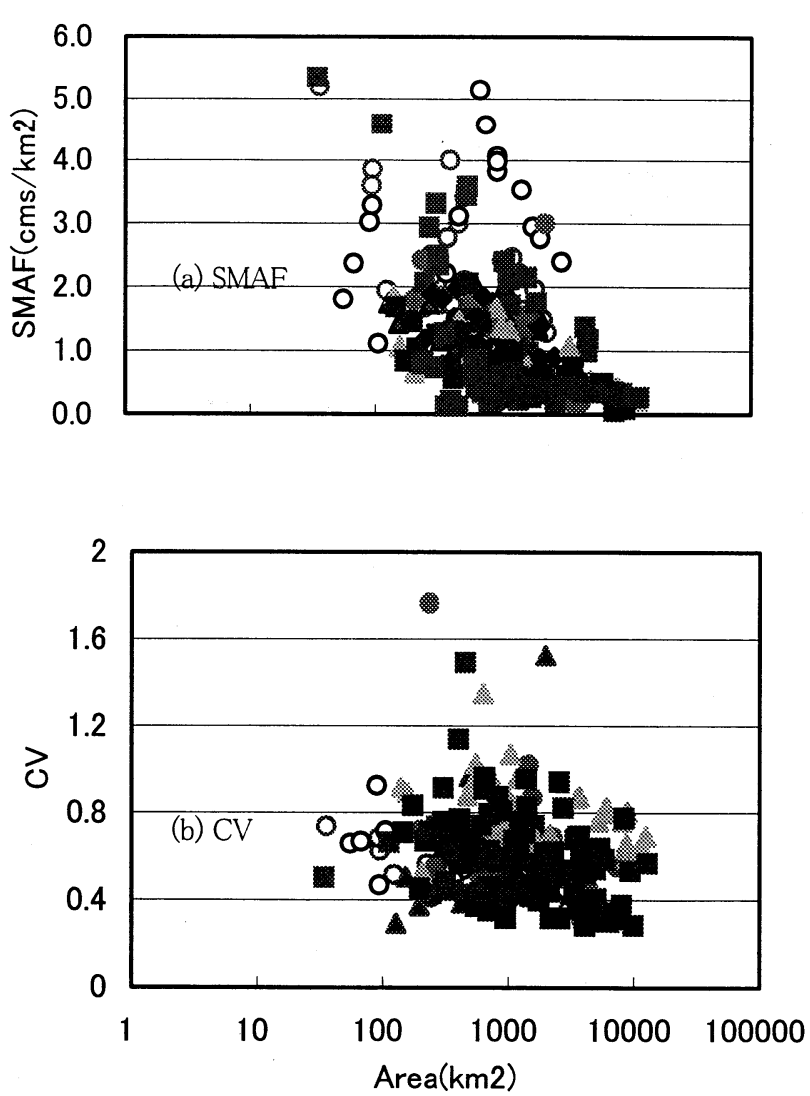

図-1 日本の流域での SMAF と CV

図一1は, 日本の流域について, (a)SMAF と流域面積, (b)CV と流域面積の関係をプロットしたものである ${ }^{4)}$. ただし, データは流量年表に依り, 20 年以上のデータ が使える流域(285 流域)のみを対象とした. 図ー1 (a)SMAF が Austria のデータを用いた結果より全体的 に大きいが, 両図とも傾向は Blöschl and Sivapalan ${ }^{1)}$ と ほぼ同様である. “CV は流域面積 $100 \mathrm{~km}^{2}$ あたりで ピークを持つ”といら研究結果 ${ }^{2)}$ もり, その理由づけ もなされてきたが, Blöschl and Sivapalan ${ }^{1)}$ では否定さ れている. すなわち, “水文レジーム” なる概念を導入 し, 流域をいくつかのレジームに分け(すなわち水文学 的に類似と考えられるいくつかの流域に分け)，それぞ れのレジームについての“CV-流域面積”関係を重ね 合わせて結果的に得られる関係が図一1のような“CV流域面積”関係であり, 異なるレジームに属す流域の データを包括的に扱って論じてもその特性はわかりに くいといら考え方による. 著者らは日本の流域をいくつ かのレジー八に分類することも試みてはいるが，それ 自体が研究要素を含むので, 完結はしていない. ただ し, いくつかの分類分けはできているので, それらの例 を示す ${ }^{4)}$. 図一2では, 北海道・東北地方の流域のうち, 春期に流出量が多い流域を対象としている.これらの 流域を「水文学的に類似な流域」すなわち「同じレジー ムに属す」と考えた.これらの流域では「融雪による流 出が卓越している」と考えられる. SMAF は明らかに右 下がりの曲線上にのっている. 特に東北地方の流域で
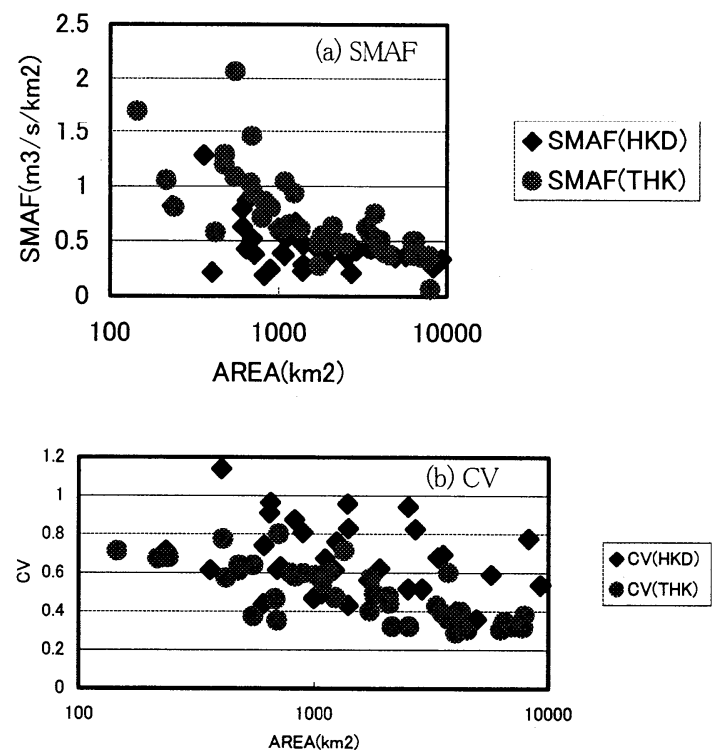

図-2 融雪流出が多い流域での(a)SMAF と(b)CV HKDは北海道, THK は東北
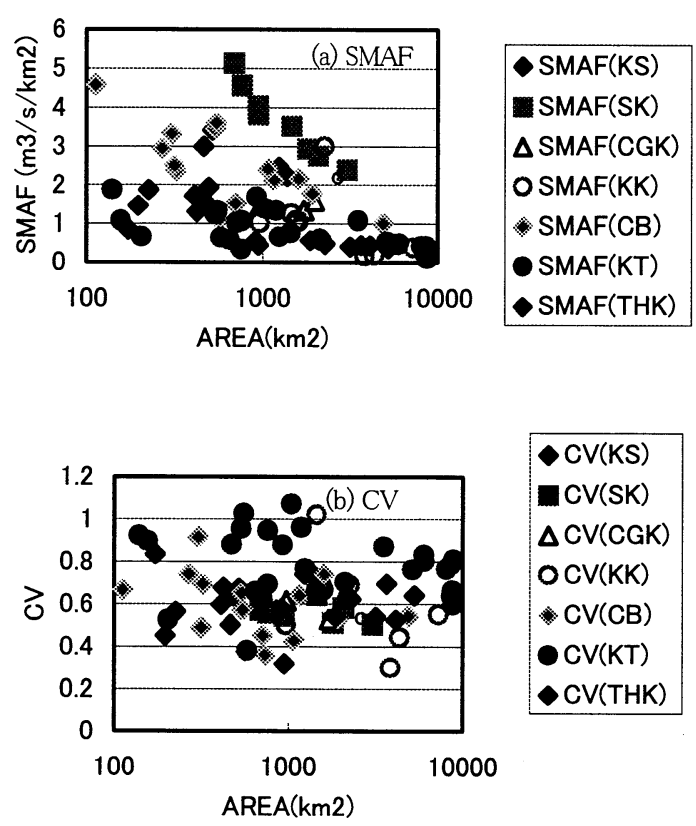

図ー3 8,9 月の流出が多い流域での(a)SMAF と(b)CV KS:九州, SK:四国 など, 地方別に表示

その傾向が著しい. また, CV に関しても, SMAF ほど はっきりはしていないが, 右下がりの曲線を描いている ことがわかる. また，図一3(a) は全国の流域のうち，8 月または 9 月に月流出量が最大になる流域だけを選 んで(それらを同一レジームに属すと仮定して) SMAF と流城面積の関係を示したものである.「地方」別に見 ると,これも右下がりの傾向を示していることは明らかで あるが，地方ごとの曲線形状の相違が何であるかを理 解するために, 数値モデルによる検討が有益と考える.

\section{3. 降雨一流出モデル}

前述の通り, 数值シミュレーションで SMAF, CV を 
求めるために, Eagleson ${ }^{5)}$ 手法を用いた. この手法で は, イベントごとのピーク流量の分布関数を求め, 年最 大流量, すなわち「イベントごとのピーク流量の極值」 が Gumbel 分布に従うといら仮定の下, その平均值す なわち MAF を再現期間との関係を用いて求める. 以 下,この手法を 3 つのサブモデル, すなわち 1) 降雨 モデル，2）流出モデル，3) 極值分布モデルに分けて 概説する. 各式導出の詳細については文献 5)を参照 されたい. なお, ここ以降, 特に断らない場合, すべて 単位系は(metre- sec 系)を用いている.

(1) 降雨モデル

降雨継続時間 $\left(t_{r}\right)$, 降雨強度 $\left(i_{0}\right)$ の確率密度関数を それぞれ式(1),(2)で表す。

$$
\begin{aligned}
& f\left(t_{r}\right)=\lambda e^{-\lambda t_{r}} \\
& f\left(i_{0}\right)=\beta e^{-\beta i_{0}}
\end{aligned}
$$

$t_{r}=t_{r}$ のときの $i_{0}$ の条件付確率, 即ち $f\left(i_{0} \mid t_{r}\right)$ は一つの イベントでの降雨量 $\left(d=t_{r} i_{0}\right)$ が大きいときには次式(3)で 表される.

$$
f\left(i_{0} \mid t_{r}\right)=\beta e^{-\beta i_{0}}=f\left(i_{0}\right)
$$

また, ポイント観測による $d$ と, 直接流出の寄与域 (面積 $A_{r}$ ) での $d_{A r}$ との間には式(4)のような関係がある とする.

$$
\begin{aligned}
& d_{A r} / d=1-\exp \left(-1.1 \zeta^{-1 / 4}\right) \\
& +\exp \left(-1.1 \zeta^{-1 / 4}-0.01 A_{r}^{*}\right)=K
\end{aligned}
$$

ここで, $\zeta=3600 \lambda, A_{r}^{*}=A_{r} /\left(1609^{2}\right)$ である.

以上より, 降雨強度が $i_{0}$ の時の「寄与域(面積; $A_{r}$ )での 平均降雨強度 $\rfloor i_{0} *$ は次式 $(5)$ の確率密度関数に従うこと になる.

$$
f\left(i_{0^{*}}\right)=f\left(i_{0^{*}} \mid A_{r}\right)=\frac{\beta}{K} e^{-\beta i_{0} / K}
$$

次に, 寄与域での損失率を流域で一定と仮定するな ら, 平均有効降雨 $i_{c^{*}}$ は次式(6)の分布に従うことになる. なお, 式(6)の $t_{r e}$ は「有効降雨の継続時間」であるが, これの確率構造は $t_{\Gamma}$ のものと同一であることが導出され ている.

$$
f\left(i_{e^{*}}, t_{r e}\right)=(\beta \lambda / K) \exp \left\{-\lambda t_{r e}-\left(\beta i_{e^{*}} / K\right)\right\}
$$

(2) 流出モデル

流出モデルは, kinematic wave 法を用いる.ここでは 「対称 2 斜面 -1 河道」の流域を考える. 斜面系, 河道 系の kinematic wave 式は, 以下の式(7),(8)で表される.

$$
\begin{aligned}
& d q / d t=i_{e^{*}} c_{c}, d y / d t=i_{e^{*}} \\
& d q / d x_{c}=i_{e^{*}}, d y / d x_{c}=i_{e^{*}} / c_{c} \\
& q=\alpha_{c} y^{m_{c}} \\
& d x_{c} / d t=\alpha_{c} m_{c} y^{m_{c}-1} \quad \text { (特性曲線) }
\end{aligned}
$$

$$
\begin{aligned}
& d Q_{s} / d t=2 q c_{c}, d A_{s} / d t=2 q \\
& d Q_{s} / d x_{s}=2 q, d A_{s} / d x_{s}=2 q / c_{s} \\
& Q_{s}=\alpha_{s} A_{s}^{m_{s}} \\
& d x_{s} / d t=\alpha_{s} m_{s} A_{s}^{m_{s}-1} \text { (特性曲線) }
\end{aligned}
$$

ここで, $q, Q$ はそれぞれ斜面, 河道の流出量, $t$ は時 間軸, $x$ は流れ方向の座標軸, $y$ は斜面流の水深, $A$ は河道流の断面積, $\alpha, m$ は斜面・河道流に関するパ ラメータであり, 添え字 $c$ は斜面流, $s$ は河道流に関す るものであることを示している. なお，以下， $m_{c}=2, m_{s}$ $=3 / 2$ として計算を進める. ここでは有効降雨継続時間 $\left(t_{r e}\right)$ 中の領域平均有効降雨 $\left(i_{e^{*}}\right)$ を一定としているが, $t_{r e}$ と $t^{*}$ の関係において, $\left[t_{r e} \geqq t^{*}\right]$ の場合には, そのイベ ントでの流路下端の最大流量 $Q_{\max }$ が式(9)で表せるこ とは容易に求まる. ただしここで, $t *$ *斜面と河道をあ わせた場合の集中時間である.

$$
Q_{\max }=A_{r} i_{e^{*}}
$$

しかし， $Q_{\max }$ の確率構造を求めるためには, $\left[t_{r e} \geqq t^{*}\right]$ でない(降雨継続時間が集中時間よりも短い)場合も考 慮する必要があり, 文献 5)ではそれらの場合について も考慮されている. $\left[t_{r e} \geqq t *\right]$ でない場合を考慮すること により, $Q_{\max }$ を求める手続き, その結果として分布関数 $F\left(Q_{\max }\right)$ の導出がかなり複雑になるが, いくつかの近似 式を使うことにより, 超過確率分布関数は以下のように 求めることができる. ただし, ここで $Q_{p}$ は直接流出の寄 与分 $Q_{\max }$ に, 基底流出分 $Q_{b}$ を加えたものである. す なわち, $Q_{\max }=Q_{p}-Q_{b}$ である. $F\left(Q_{p}\right)$ は,

$$
F\left(Q_{p}\right)=I_{0}^{*} \int_{0}^{A_{c}} \exp \left[-\frac{\beta\left(Q_{p}-Q_{b}\right)}{K A_{r}}\right] \cdot f\left(A_{r}\right) d A_{r}
$$

である.ここで, $I_{o}{ }^{*}$ は $A_{r}, Q_{p}, Q_{b}$ 等の関数であるが, 具 体的な関数形については記述を省略する.さて, 式 (10)を積分すると, 式(12)が得られる.ただし, 実際には $A_{r}$ は時空間的に変化する変数であるが, ここでは Eagleson と同じく,

$$
f\left(A_{r}\right)=\frac{2}{A_{c}}\left(1-\frac{A_{r}}{A_{c}}\right)
$$

を用いることとする. 結果的に, $Q_{p}$ の超過確率分布関 数は, 式(12)のように求めることができる.

$$
\begin{gathered}
F\left(Q_{p}\right)=I_{0}^{*}\left\{\frac{\left(A_{c}-k\right)}{A_{c}} \exp \left(\frac{k}{A_{c}}\right)\right. \\
\left.+\frac{k\left(2 A_{c}-k\right)}{A_{c}^{2}} \Gamma\left(0,-\frac{k}{A_{c}}\right)\right\} \\
\text { ただし, } k=\frac{-\beta\left(Q_{p}-Q_{b}\right)}{K} \text { である. ここで, } \\
\Gamma(a, z)=\int_{z}^{\infty} t^{a-1} e^{-t} d t
\end{gathered}
$$

である. 
(3) 極值分布モデル

最大流量の超過確率分布関数は, 前節の式(12)のよ うに表されるが, 年最大流量が Gumbel 分布に従うと仮 定すると, その平均值である MAF は, 再現期間 $T_{E}$ $=1.78$ 年 $\left(T_{M}=2.33\right.$ 年) をもつ極值と考えられる ${ }^{7}$. ここ に, $T_{M}, T_{E}$ はそれぞれ, Chow ${ }^{7)}$ にる annual maximum series, annual exceedence series に対する再現期間 (年)である. いま, $n$ を毎年の直接流出となる有効降雨 を生ずるイベントの発生回数の平均値とすると,

$$
T_{E}^{-1}=n F\left(Q_{p}\right)
$$

が導かれるので, $T_{E}=1.78$ を式(14)を代入することによ り, 平均值(=MAF)が求められる. さらに, Gumbel 分布 のパラメータ $u, \alpha$, 標準偏差 $s, T_{M}$ の間には

$$
\begin{gathered}
\alpha=\frac{\sqrt{6}}{\pi} s \\
y_{T}=-\ln \left[\ln \left(\frac{T_{M}}{T_{M}-1}\right)\right] \\
x_{T}=u+\alpha y_{T}
\end{gathered}
$$

なる関係があるので, 再現期間として適当な 2 つの值 選ぶと, 式(14)から「それぞれの再現期間に対する極 值」が求まる.つぎにそれらの值を式(15),(16),(17)に代 入する $\left(x_{T}=Q_{p}\right.$ である $)$ こにより, $s$ が求まる. $\mathrm{CV}$ は, 定義通り, (標準偏差)/(平均值)で求められる.

\section{4. 結果と考察}

まず, Eagleson ${ }^{5,6)}$ が使用した米国 Connecticut River 流域に適応するパラメータと同様のパラメータを使用し た計算を control run として行った.つぎに, いくつか のパラメータを変えて計算を行い, 感度分析を行った. control run におけるパラメータ, その他の計算におけ るパラメータは表ー1のとおりである.

\section{(1) SMAF}

図ー4は, 表一1に示したケースについて, SMAF の計算結果を示したものである. ただし, 横軸は対数 軸を用いている. 各曲線は, 「流域面積が増加すると, SMAF が減少する」といら傾向を示している. 図一2で もその傾向は明らかであり, 図一ろにおいても, 各地方 ごとのデータに注目すれば, その傾向が見られる.ここ で, モデルを介してその理由について考察してみる.

本研究で用いたモデルは前述の式(12)で表される 確率分布関数を用いたものである. ただし，この式の導 出過程にはいくつかの近似が用いられており，またそ の「近似を用いた」所以たる式形の複雑さ故, 解析的な 扱いは困難である. そこで, 今まで述べたモデルを簡
表ー1 主なパラメータ. No.1 (control run) 以外は, No.1 と 異なるもののみ記述してある. 単位は全て m-sec 系

No.1 $\quad \beta=4251969 \quad \lambda=0.0000361 \quad P=1.1176 \quad \phi_{1}=0.47$
$\phi_{2}=0.58 \quad \alpha_{c}=10.0 \quad \alpha_{s}=0.1$

No.2,3,4 それぞれ $\alpha_{s}$ がNo.1の $2^{1 / 2}, 5^{1 / 2}, 10^{1 / 2} 2$ 倍

No.5,6,7,8 それぞれ $\phi_{2}$ が $0.5,0.4,0.3,0.2$

No.9 $\lambda$ が No.1の 0.5 倍, $\beta$ が 2 倍

No.10 $\lambda$ がNo.1の2 倍, $\beta$ が 0.5 倍

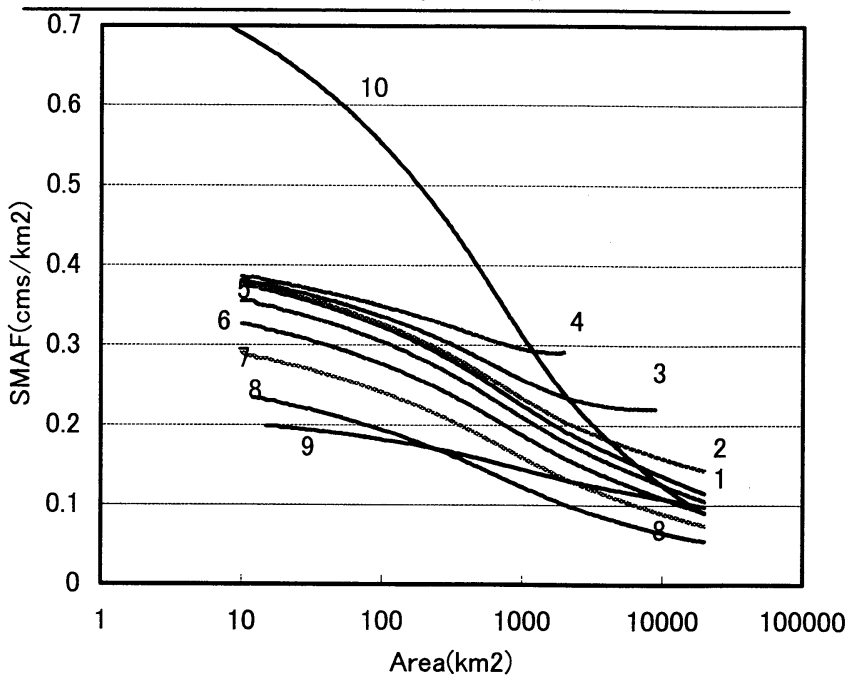

図一4 SMAF の計算値

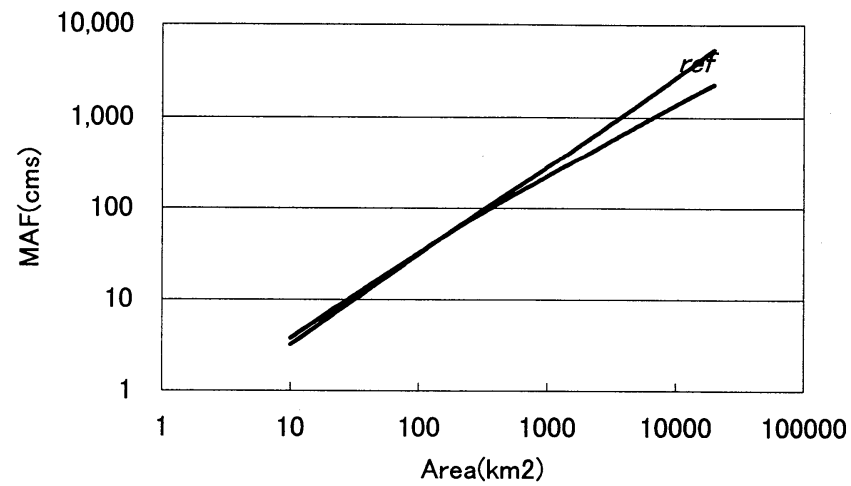

図一5 二つのてデルによるMAF の比較：IU厂 と表示され ているのが「簡易モデル」による計算結果.

略化した「簡易モデル」を導入することとする. すなわち, 式(10)〜(12)を導出する際に, 前述のように $\left[t_{r e} \geqq t^{*}\right]$ なる条件を仮定すれば, ピーク流量は式(9)で求められ, 式(12)は $Q_{p}$ に関して陽に次式(18)のように表される ${ }^{6)}$. 以下, 式(12) によるモデルを「詳細モデル」, 式(18)を 式(12)の替わりに用いたモデルを「簡易モデル」と称す ることとする.

$$
Q_{p}=\frac{A_{c} K}{3 \beta} \ln \left(T_{E} n\right)+Q_{b}
$$

さて, 図一5には,「詳細モデル」を用い, control run として行った計算で得られた MAFと，「簡易モデル」に よる MAF(図中, refと表示)をプロットした.この図より, 流域面積が $1000 \mathrm{~km}^{2}$ 以下の場合には,「簡易モデル」 が「詳細モデル」による結果を充分近似していることが 
わかる.よって, ここでは, 解析的に用いることが容易 な式(18)を代替式として用いることとする.

式(18)のうち， $Q_{b}$ は基底流量を表す項であるが, こ れは次式(19)のように表される ${ }^{5,6)}$ (式(10)における $Q_{b}$ も同様である).

$$
Q_{b}=\left(1-\phi_{2}\right) \phi_{1} P A_{c}=B A_{c}
$$

ここに, $P$ は年降水量, $\phi_{1}$ は流出率， $\phi_{2}$ は(直接流出 量)/(総流出量)の平均値, $A_{c}$ は流域面積である. これ らの值は, それぞれのケースで計算条件として与えら れるものであり, 一つのケースでは同じ值を使用するの で, 式(19)中に示したように, 定数 $B$ を用いて表示でき る. 式(18),(19)から,「簡易モデル」による SMAFは,

$$
S M A F=\frac{M A F}{A_{c}}=\frac{K}{3 \beta} \ln (1.79 n)+B
$$

と変形できる. いま, 図一4等における SMAF の曲線 形状を論じようとしているが, 式(20)の最右辺のうち, $K$ 以外は正の定数であり, かつ

$$
\begin{aligned}
& \frac{d K}{d A_{c}}=-\left\{\frac{0.01}{(1609)^{2} \cdot 3}\right\} \\
& \cdot \exp \left\{-1.1 \zeta^{-1 / 4}-0.01 A_{c} /\left(1609^{2} \cdot 3\right)\right\}
\end{aligned}
$$

は明らかに負值をとる.よって, SMAF が流域面積に 対して単調減少であることが導かれる. なお, ここで, 「直接流出に寄与する面積 $\lrcorner A_{\mathrm{r}}$ は時空間的に変化する 変数で, 本稿では式(11)のような確率密度関数に従うと 仮定しているが, $K$ を求める際には, $A_{r}=\mathrm{E}\left[A_{r}\right]=A_{d} / 3$ なる関係を用いている.

次に, 図一 4 と図一2,3を比較すると, 実流域での データが「下に凸」な曲線形状を示すのに対し, 本モ デルで計算した結果が「特に流域面積の小さい時に上 に凸」な形状を示していることがわかる. そこで, ここで も「簡易モデル」を用いた考察を行う. 本研究では, (SMAF·CV) 対 (対数軸で表された流域面積)の曲線 形状を比較して流出特性を考えようとしているので, こ こでは $d^{2}(S M A F) / d\left(\log _{10} A_{c}\right)^{2}$ による検討をしなければ 意味がない。

ここでも $A_{r}=\mathrm{E}\left[A_{r}\right]=A_{d} / 3$ を仮定することにより， $A_{r}^{*}=A_{r} /(1609)^{2}=A_{c} /\left\{(1609)^{2} \cdot 3\right\}$ が成立するの で, 式(4) は次式(4)' のように変形できる.

$$
\begin{aligned}
& K=1-\exp \left(-1.1 \zeta^{-1 / 4}\right) \\
&+\exp \left\{-1.1 \zeta^{-1 / 4}-0.01 A_{c} /\left(1609^{2} \cdot 3\right)\right\} \\
& \text { ここで, } A_{x}=\log _{10} A_{c} \text { とすると, }
\end{aligned}
$$

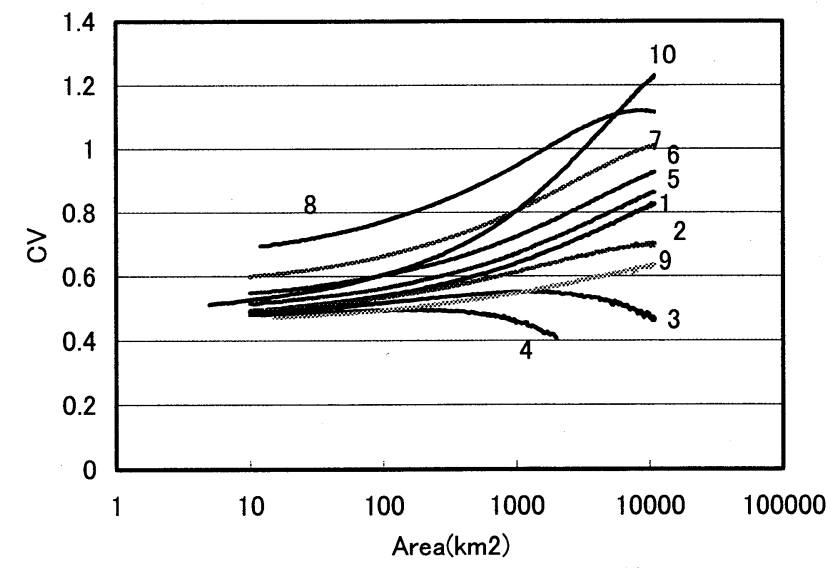

図ー6 詳細モデルによるCVの計算值

$$
\begin{aligned}
& \frac{d^{2} K}{d A_{x}^{2}}=\left\{\frac { 0 . 0 1 } { 3 \cdot ( 1 6 0 9 ) ^ { 2 } } ( \operatorname { l n } 1 0 ) ^ { 2 } A _ { c } \operatorname { e x p } \left(-1.1 \lambda^{-1 / 4}\right.\right. \\
& \left.\left.-\frac{0.01}{3 \cdot(1609)^{2}} A_{c}\right)\right\}\left(\frac{0.01}{3 \cdot(1609)^{2}} A_{c}-1\right)
\end{aligned}
$$

となるから,「 $A_{c}$ が約 $777 \mathrm{~km}^{2}$ より小さいときには2階微 分が負, すなわち曲線は上に凸，それより大きいときに は下に凸になる」といら結果が得られる. 図一2,3の実 流域のデータを見る限り，以上の結果を否定するもの ではない, すなわち流域面積が比較的大きいときに曲 線の形状が下に凸でかつ単調減少になってはいるが, 流域面積 100〜 $1000 \mathrm{~km}^{2}$ のデータが少ないので, 直ち に肯定するものでもない.

つぎに, 感度分析の結果(図一4)から, 以下のような ことがわかる. ここで, 図中の曲線に付してある数字は, 表-1中の (数值) 実験番号に対応する.

Connecticut River 流域における水文パラメータを使 用した control run と比較して, 大きく曲線形状が異 なっている, すなわち大きな影響を与えたのは降雨の 構造を変えたケース $(9,10)$ である. $P($ 年平均降雨量 $)$ を 全てのケースで同じとしたため, $\mathrm{E}\left[t_{r e} i_{0}\right]=1 /(\beta \lambda)$ は 一定である. No.9 のケースでは $\beta$ が control run の2 倍 (すなわち平均降雨強度が半分), No.10 のケース では control run の半分 (平均降雨強度が2倍) となっ ている.このように降雨の構造が大きく影響を与えるの は, 式(9)から明白である.

河道勾配が $m$ 倍になると, kinematic wave 式の $\alpha_{s}$ が $m^{1 / 2}$ 倍になるが, $\alpha_{s}$ を大きくすると, SMAF が大き くなる. また， $\phi_{2}$ を小さく(基底流量 $Q_{b}$ を大きく)すると, SMAFは小さくなる.

本研究では, SMAF-面積曲線の形状による流出特 性の解析を目標としているので, 条件の違いによる SMAF の大小関係よりも, 曲線形状の変化を把握する ことが大事であると考えるが, 計算の結果, 降雨構造を 変えることにより, 曲線形状が大きく変わること, 基底流 量(融雪流出を含む)の変化に対しては「形状」はそう 大きく変わらないこと， $\alpha_{s}$ の変化は, 基底流量よりは 
「形状」を変える作用があることなどが示唆されている. 図一3の地方別の曲線形状の相違は, 今までの結果 から考えて(シミュレーションの結果だけから考えると)， 降雨の構造， $\alpha_{s}$ に関係するパラメータの違いなどが理 由として考えられる.

\section{(2) $\mathrm{CV}$}

図一6は,「詳細モデル」を用て計算で求めた CV と 流域面積の関係をプロットした図である. 本稿ではモデ ル計算する際に Connecticut River 流域のパラメータを そのまま用い, 定性的な比較を介してモデルの妥当性 を検討しようとしているため, 図一1，2，3と比較してモ デルの妥当性を直ちに論ずることはできないと考える が, ここではモデル計算による CV 曲線の性状につい て考察してみる.

図一2,3の CV 曲線は, 流域面積が大きくなるに 従って若干減少する傾向にある. しか儿, 計算值(図一 6) では流域面積が $1000 \mathrm{~km}^{2} \sim 10000 \mathrm{~km}^{2}$ 以上になる までは, CV は増加する.ここでも, 前節と同じく「簡易 モデル」を用いて解析的に検討する.

MAF が Gumbel 分布に従うと仮定し，(本モデルで は)その分散 $s$ を, 以下のようにように求めている(参 照:式(15),(16),(17),(18),(19)). すなわち, 適当な再現 期間 $T_{E 1}, T_{E 2}$ に対応する $y_{T}$ の值を $y_{T 1}, y_{T 2}$ とし, 同 じく対応する $x_{T}$ の值を $x_{T 1}, x_{T 2}$ とすると,

$$
s=\frac{\pi}{\sqrt{6}} \alpha=\frac{\pi}{\sqrt{6}} \frac{\left(x_{T 1}-x_{T 2}\right)}{\left(y_{T 1}-y_{T 2}\right)}
$$

$T_{E *}$ を MAF に対応する再現期間とすると, 定義に従い， CV は次式で求められる.

$$
\begin{aligned}
& C V=\frac{s}{M A F}=\frac{\pi}{\sqrt{6}\left(y_{T 1}-y_{T 2}\right)} \\
& \times\left[\frac{A_{c} K}{3 \beta}\left\{\ln \left(T_{E 1} n\right)-\ln \left(T_{E 2} n\right)\right\}\right] /\left\{\frac{A_{c} K}{3 \beta}\left(T_{E^{*}} n\right)+B A_{c}\right\}
\end{aligned}
$$

基底流出が直接流出より充分小さいときには

$$
C V=\frac{\pi}{\sqrt{6}\left(y_{T 1}-y_{T 2}\right)}\left\{\ln \left(T_{E 1} n\right)-\ln \left(T_{E 2} n\right)\right\} /\left\{\left(T_{E^{*}} n\right)\right\}
$$

となるので, 結局,「簡易モデルによる CV」は流域面積 に依らず，一定值をとることになる.「詳細モデル」を使 用した結果(図一6)を見ると，「簡易モデル」を用いた ここでの解析結果と違い，CV は一定値にはなってい ないが,これは「詳細モデル(式 12)」では「簡易モデル (式 18)」より現象を丁寧に記述しているためである.た だし, 両モデルとも基本的なフレームワークは同一であ ることから, ここでの解析，すなわち式(23)〜 (25)による 検討をとおして, $K$ を求める際に, $A_{r}=\mathrm{E}\left[A_{c}\right]=A_{c} / 3$ を 用いていること, ひいては式(11)のような $A_{r}$ の(時間依 存性がない等, かなり簡単な)構造を仮定していること
に対して, 検討が必要であることが示唆されていると考 える. なお, CV に関する感度分析の結果は, 降雨構 造の影響が大きいなど, 前節での SMAFに関するもの と定性的には類似である。

\section{5. 結論}

著者らは, SMAF, CV と流域面積の関係をもとに, 降雨一流出過程をより深く理解しようとしている. その 過程で数值モデルを用いることを考えているが, 本稿 では「数值モデルで実流域での SMAF, CV 等の挙動 を再現できるか否か」に絞った報告を行った. 定量的な 検討は, 日本の対象流域の水文学的パラメー夕同定後 に行うが, 定性的検討の結果, SMAF については本モ デルでの再現は可能と考える. しかし CV を求めるた めには問題点があると考えられることから, 今後は降雨 構造の同定, 直接流出の寄与域決定法, 総じて言えば 降雨一流出過程における時·空間変動構造について, 実データを用いたさらなる検討を行う必要があると同時 に, 「この種のモデルで CV の変化傾向が再現できる のか」を解析的に調べる必要があると考える. さらに, 貯水池等の人工構造物の影響が大きい流域を扱う場 合には何らかの工夫が必要なことは明白である. 現段 階ではそれらの影響を考慮していないが, モデルに影 響を反映させることも課題と考える。

謝辞: 本研究を行うにあたり, 文部省科研費の補助を受 けた. 深謝いたします. 99 年度土木学会年講において 有益なコメントを下さった方々にも謝意を表します。

\section{参考文献}

1) Blöschl, G. and Sivapalan, M.: Process controls on regional flood frequency: Coefficient of variation and basin scale, WRR, Vol. 33, pp. 2967-2980, 1997.

2) Smith, J.A.: Representation of basin scale in flood peak distributions, WRR, Vol. 28, pp. 2993-2999, 1992.

3) 宝䵅: 国際水文学計画(IHP)及びFRIENDプロジェクトの課題 と現況 一東南アジア・太平洋地域の活動を中心として一, 水 文・水資源学会誌, 第11巻, pp. 274-284, 1998.

4) 葛葉泰久ら: 年最大流量の変動係数を用いた流出特性の解 析, 第54回土木学会年講概要集第2部, pp. 642-643, 1999.

5) Eagleson, P.S.: Dynamics of flood frequency, WRR, Vol. 8, pp. 878-898, 1972.

6) Eagleson, P.S.: The Stochastic kinematic wave, in Systems Approach to Hydrology, pp.202-225, Water Resources Publications, Fort Collins, 1971.

7) Chow, V.T., Maidment, D.R., and Mays, L.W.: Applied hydrology, pp. 380-391, Mcgraw-Hill, 1988.

(1999. 9. 30受付) 